\title{
An Amidoximated-UHMEPE Fiber for Selective and High Efficient Removal of Uranyl and Thorium from Acid Aqueous Solution
}

\author{
Chan Jin'1, Jiangtao Hu1, Jianqiang Wang', Chunyun Xie', Yajun Tong², Linjuan Zhang1, Jing Zhou', \\ Xiaojing Guo ${ }^{1}$, Guozhong $\mathrm{Wu}^{1^{*}}$ \\ ${ }^{1}$ Center for Thorium Molten Salt Reactor System, Shanghai Institute of Applied Physics, Chinese Academy of Sciences, Shanghai, China \\ ${ }^{2}$ Shanghai Synchrotron Radiation Facility, Shanghai Institute of Applied Physics, Chinese Academy of Sciences, Shanghai, China \\ Email: *wuguozhong@sinap.ac.cn
}

How to cite this paper: Jin, C., Hu, J.T., Wang, J.Q., Xie, C.Y., Tong, Y.J., Zhang, L.J., Zhou, J., Guo, X.J. and Wu, G.Z. (2017) An Amidoximated-UHMEPE Fiber for Selective and High Efficient Removal of Uranyl and Thorium from Acid Aqueous Solution. Advances in Chemical Engineering and Science, 7, 45-59.

http://dx.doi.org/10.4236/aces.2017.71005

Received: August 24, 2016

Accepted: December 27, 2016

Published: December 30, 2016

Copyright $\odot 2017$ by authors and Scientific Research Publishing Inc. This work is licensed under the Creative Commons Attribution International License (CC BY 4.0).

http://creativecommons.org/licenses/by/4.0/ (c) (i) Open Access

\begin{abstract}
High efficient removal and recovery of uranium and thorium from nuclear waste solution are essential for environmental preservation and fuel recycle. A new polymer fiber adsorbent (UHMEPE- $g$-PAO fiber), prepared by amidoximation of grafted polyacrylonitrile onto Ultra High Molecular Weight Polyethylene (UHMWPE) fiber, was used to remove the uranyl and thorium ions from acid aqueous solutions and its performance was carefully investigated. It was found that uranyl ion can penetrate the fiber through the connected pore structures, forming $\left(\mathrm{UO}_{2}\right)\left(\mathrm{R}-\mathrm{C}\left(\mathrm{NH}_{2}\right)-\mathrm{NO}\right)_{2}$ chelates with the amidoxime groups within the fiber. Two amidoxime groups (U-N and $\left.\mathrm{U}-\mathrm{O}_{\mathrm{eq}}\right)$ and two water molecules $\left(\mathrm{U}-\mathrm{O}_{\mathrm{eq} 2}\right)$ are bound to uranyl ion in the fiber. On the contrary, thorium ions are adsorbed mainly on the fiber surface in the form of $\mathrm{Th}(\mathrm{OH})_{4}$ precipitate that blocks the entrance of $\mathrm{Th}^{4+}$ ion into fiber pores. The maximum included other two capacities of uranyl and thorium ions were estimated to be $262.01 \mathrm{mg} / \mathrm{g}$ and $160 \mathrm{mg} / \mathrm{g}$ at room temperature with $\mathrm{pH} 3.0$, respectively. The results also indicate that the UHMWPE- $g$-PAO fiber has higher adsorption selectivity for uranyl ion than thorium ion. Uranium and thorium oxide particles were obtained as the ultimate product after sintering of the fiber adsorbent. This novel and environmentally friendly adsorption process is feasible to extract uranium or thorium from acidic aqueous solution.
\end{abstract}

\section{Keywords}

UHMWPE Fiber, Uranium Ions, Thorium Ions, Selective Absorption Mechanism, XAFS, SR-FTIR

\section{Introduction}

Nuclear energy is considered as one of the best sources of clean energy without pollut- 
ing the environment by ejecting carbon dioxide. Meanwhile, the high level liquid waste, containing uranium, minor actinides, or thorium, will be produced. One major challenge is the disposal of nuclear waste [1] [2] [3] including the removal and recovery of radionuclides with minimum impact on the environment. From the point view of uranium resources and environmental protection [4] [5], separation and recovery of the essential uranium element in nuclear waste solution are also of great significance. Solid phase extraction [6] [7] (SPE) has been considered to be one of the most effective methods for recovery of materials because of its simplicity, low cost and wide adaptability [8].

In many cases, the liquid waste is present as acidic aqueous solutions. The adsorbent should have an adequate stability in the acidic aqueous solutions. Among the various solid-phase extractants, UHMWPE fiber adsorbent may have potential application due to its higher tensile strength, excellent acid/base stability, and ease of handling. UHMWPE fiber alone does not have any capability to capture metal ion from aqueous solution, and functional ligands have to be anchored to the surface of UHMWPE fiber. Recently, numerous scientists have focused on sorbents combined with organic functional groups such as amino [9], polyhydroxyethylmethacrylate [10] [11], amidoxime (AO) [7] [12] [13], mercapto [14] etc. The sorbents with binding groups are promising candidates for sorption of actinides. Amidoxime groups have high selectivity and capacity for sorption of uranium ions in aqueous solution with $\eta^{2}$-binding mode [7] [12] [13]. For example, the AO-based (AO: amidoxime) polyethylene nonwoven fabric was used for sequestering uranium from seawater and separate uranium from very lean sources of aqueous solutions at near neutral $\mathrm{pH}$ condition [15] [16]. The MWCNT-g-AO [13] has previously been reported of the uranium sorption capacity of $145 \mathrm{mg} \cdot \mathrm{g}^{-1}$ and a strong selectivity at $\mathrm{pH} 4.5$. The electrospun polyvinyl alcohol/titanium oxide nanofiber adsorbents modified with mercapto groups show larger capacity for thorium than uranyl in aqueous solution [14]. The polyhydroxyethylmethacrylate-pumice composites [10] possess high affinity to the uranium and thorium ions at different $\mathrm{pH}$, ion concentration, and ionic strength. The chitosan/clinoptilolite sorbents [17] also have high affinity for uranium and thorium ions in simulated radioactive solution in the presence of $\mathrm{Cu}^{2+}, \mathrm{Fe}^{2+}$ and $\mathrm{Al}^{3+}$.

Polyacrylonitrile can be grafted onto the surface of UHMWPE fiber by pre-irradiation method [18] and the amidoximated UHMWPE (UHMWPE-g-PAO) fiber can be obtained by treating with hydroxylamine. The objective of this work is to explore the use of UHMWPE-g-PAO fiber for selective adsorption and recovery of uranium and thorium from acidic aqueous solution. Micro structure and distribution of adsorbed ions in the fiber adsorbent were analyzed by $\mu$-CT, TEM, FTIR and EXAFS in order to understand the adsorption mechanism. The ultimate product of uranium and thorium was obtained by sintering of the fiber adsorbent. The entire process is feasible and environmentally friendly.

\section{Materials and Methods}

Sample Preparation. UHMWPE- $g$-PAO fibrous adsorbent was prepared by $\gamma$-irradiation induced graft polymerization of acrylonitrile (AN) and acrylic acid (AA), followed by 
amidoximation. The detail reaction process was outlined in our previous work [18] [19] [20]. The degree of grafting (DG) [20] of the obtained UHMWPE fiber was $150 \%$, determined by calculating the weight increment ratio.

The UHMWPE- $g$-PAO fiber was soaked in aqueous solutions of $\mathrm{UO}_{2}\left(\mathrm{NO}_{3}\right)_{4}$ and $\mathrm{Th}\left(\mathrm{NO}_{3}\right)_{4}$ individually, and their mixed solution as well, at $\mathrm{pH} 3$ for $24 \mathrm{~h}$ at room temperature. The concentrations of uranyl ion and thorium ion in the acidic aqueous solution were varied from 1 to $100 \mathrm{mM}$. The fiber adsorbent samples were taken out and washed with pure water for three times, then dried overnight in the drier with the temperature about $65^{\circ} \mathrm{C}$.

Microstructure Investigation. The X-ray tomography was performed at the X-ray imaging and biomedical application station (BL13W1) of the Shanghai Synchrotron Radiation Facility (SSRF). The storage ring was operated at $3.5 \mathrm{GeV}$. The X-ray passing through the samples was converted into visible light by a YAG: Ce scintillator $(200 \mu \mathrm{m}$ thinkness). Dozens of fiber adsorbent samples were fixed in plastic pipe and placed at a distance of $14 \mathrm{~cm}$ from the CCD camera (14 bit dynamic, $2048 \times 2048$ pixel array), yielding a pixel size of $0.74 \mu \mathrm{m}$. Seven hundred and twenty radiographs were taken at regular increments over $180^{\circ}$ of rotation, each with an exposure time of $1 \mathrm{~s}$ and the beam energy of $18 \mathrm{keV}$. The light-field images and dark-field images were also collected during the experiment to correct for electronic noise and variations in the X-ray source brightness. Projection images were reconstructed using the PITRE software developed by SSRF and INFN [21]. The 3D data was analyzed and displayed using Avizo Fire software [22] [23].

The fiber adsorbent samples were embedded in Epon812. Ultra-thin plates $(120 \mathrm{~nm})$ were prepared by ultramicrotome (UC6, Leica Ltd. Co, Germany) and transferred onto 200-mesh copper grids. The ultrastructure was observed with transmission electron microscopy (TEM, Tecnai G2 F20 S-Twin, FEI), operated at accelerating voltage of 200 $\mathrm{kV}$ in high angle annular dark field-scanning transmission electron microscopy (HAADF-STEM).

Crystalline Structure Identification. $\mu$-SR-FTIR experiment was performed at beamline BL01B at Shanghai Synchrotron Radiation Facility (SSRF). The Nicolet 6700 FTIR spectrometer is equipped with a Nicolet Continuum Microscope, MCT-A detector, measuring range $4000-700 \mathrm{~cm}^{-1}$. The $\mu$-SR-FTIR of single fiber absorbent sample was collected with the spot of $20 \mu \mathrm{m} \times 20 \mu \mathrm{m}$. All of fiber absorbent samples were taken in transmission mode. For each measurement, 128 scans were recorded with a resolution of $4 \mathrm{~cm}^{-1}$.

EXAFS spectra of $\mathrm{UO}_{2}\left(\mathrm{NO}_{3}\right)_{4}$ solution, $\mathrm{Th}\left(\mathrm{NO}_{3}\right)_{4}$ solution and fiber adsorbent samples were collected at the $\mathrm{U} \mathrm{L}_{\mathrm{III}}$-edge $(17,166 \mathrm{eV})$ and $\mathrm{Th}_{\mathrm{III}}$-edge $(16,300 \mathrm{eV})$ using a double crystal monochromator (Si 111) in a transmission mode at room temperature on Beamline BL14W1 of SSRF. The EXAFS analysis was performed with Athena and Artemis packages [24] based on the IFEFFIT program [25]. For the element uranium, the $k$-space range was set from 2.93 to $17 \AA^{-1}$, and the fitting was performed in the $R$-space (1.45 - $2.9 \AA)$ using FEFFIT. The theoretical backscattering phase and amplitude functions for the fitting were calculated using the FEFF 8.2 code [26] [27] [28]. For the element thorium, the $k$-space range was set from 2.95 to $12 \AA^{-1}$, and presented in 
$R$-spaces. Meanwhile, the $\mathrm{Th}(\mathrm{OH})_{4}$ was taken as reference sample.

Concentration Measurement. Each of the fiber adsorbent samples was digested by 4 $\mathrm{ml}$ of the pure $65 \% \mathrm{HNO}_{3}$ (highest grade available) with heating in microwave oven (Milestone Ethos). After microwave digestion, each digest was transferred into a beaker and diluted with pure water to a final volume of $20 \mathrm{ml}$. The concentrations of $\mathrm{U}$ and $\mathrm{Th}$ elements were analyzed by ICP-AES (Optima 8000, Perkin Elmer). The accuracy of the analytical technique was confirmed using a reference material (GBW04102).

Ultimate Products. The fiber adsorbent samples were collected, and conducted in an electric muffle furnace in the presence of air to $1200^{\circ} \mathrm{C}$ for $12 \mathrm{~h}$. The morphology of ultimate processing products was observed with a scanning electron microscope (SEMEDX, LEO 1530 VP, Zeiss).

\section{Results and Discussion}

\section{The distribution of uranyl and thorium in the UHMWPE- $g$-PAO fiber}

Considering the different X-ray absorption coefficients of uranyl, thorium and UHMWPE fiber, the 3D distributions of uranyl and thorium in UHMWPE- $g$-PAO fiber were determined by SR- $\mu$-CT without damaging the samples, as shown in Figure 1. SR- $\mu$-CT is an effective tool for the visualization of the arbitrary cross section (slice) in the samples. Therefore, it is possible to analyze the morphological characteristics of the slice. As shown in Figure 1(a), the UHMWPE- $g$-PAO fiber remained uniform after soaking with $100 \mathrm{mM} \mathrm{UO}_{2}\left(\mathrm{NO}_{3}\right)_{4}$ solution, and loaded uranyl compound distributed
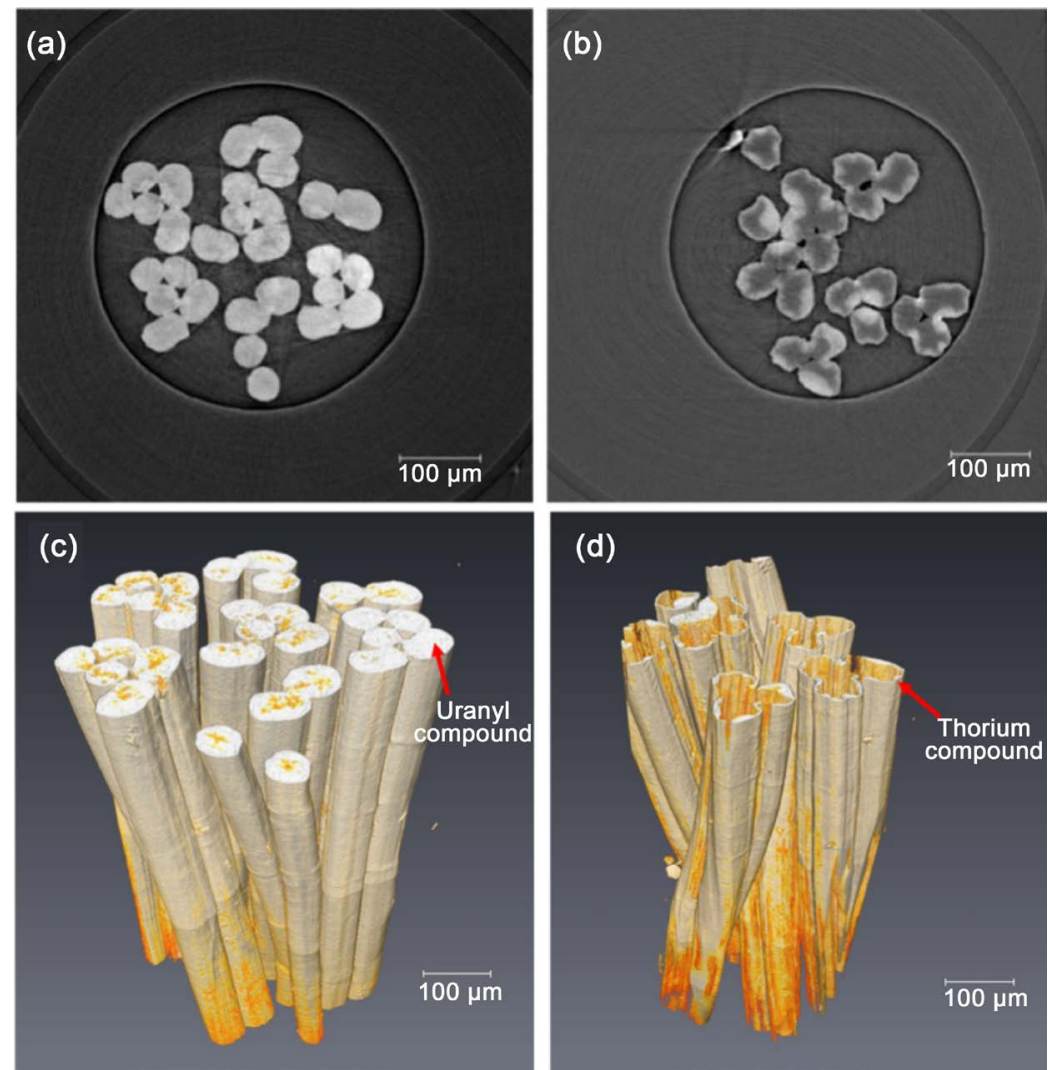

Figure 1. The slice and 3D structure of UHMWPE- $g$-PAO fiber soaked with $100 \mathrm{mM} \mathrm{UO} \mathrm{UN}_{2}\left(\mathrm{NO}_{3}\right)_{4}$ solution ((a) and (c)) and $100 \mathrm{mM} \mathrm{Th}\left(\mathrm{NO}_{3}\right)_{4}$ solution ((b) and (d)). 
through the whole cross section in every slice. However, after the soaking with $100 \mathrm{mM}$ $\mathrm{Th}\left(\mathrm{NO}_{3}\right)_{4}$ solution, the surface of UHMWPE- $g$-PAO fiber was distorted and thorium compound only existed in the surface of the fiber (Figure 1(b)). It was also proven by the SEM and EDX results as shown in Figure S1. The orange regions are the signature of the uranyl compounds and fiber itself as shown in Figure 1(c). On the other hand, the silvery white region should be the thorium compounds in the fiber as shown in Figure 1(d). The calculated volume fractions of uranyl and thorium compound, indicated in 3D tomography, were approximately 95\% and 9\%, respectively. It means that large amount of the uranyl compounds enter into UHMWPE-g-PAO fiber without changing the fiber's morphology. However, the thorium only existed on the surface and changed the surface morphology of the fiber. It might be caused by the different absorption mechanism of UHMWPE- $g$-PAO to uranyl and thorium ions.

Ultrastructure characterizations of UHMWPE- $g$-PAO fiber soaked with water, 100 $\mathrm{mM} \mathrm{UO}_{2}\left(\mathrm{NO}_{3}\right)_{4}$ solution and $100 \mathrm{mM} \mathrm{Th}\left(\mathrm{NO}_{3}\right)_{4}$ solution are shown in Figure 2. After soaking with water, it looks like a gel with uniform pore structure as shown in Figure 2(a). The pore diameter was about $25 \mathrm{~nm}$ to $100 \mathrm{~nm}$ at the edge of the fiber (Figure 2(d)), but was less than $10 \mathrm{~nm}$ inside the fiber (Figure 2(g)). Meanwhile, the pore size in the UHMWPE- $g$-PAO fiber is much larger than the size of uranyl ions and thorium ions. Furthermore, it was also found that all the pores were connected. Such pore structure of the fiber could provide more channels and active sites for the collected ions to go inside [29] [30]. After soaking with $100 \mathrm{mM} \mathrm{UO}_{2}\left(\mathrm{NO}_{3}\right)_{4}$ solution, uniform pore structure is also seen in the fiber (Figure 2(b)), the pore diameters both at edge and inside of fiber are larger than that of fiber soaked with water. It is larger than $150 \mathrm{~nm}$ and $100 \mathrm{~nm}$ at the edge and inside of the fiber, respectively. However, the fiber surface became cured, and not gelatinous anymore. It means that the uranyl ion might go inside through the connected pore structure, and occupy the active sites of the fiber. Therefore, the uranyl ions are distributed evenly in the whole section of the fiber. After soaking with $100 \mathrm{mM} \mathrm{Th}\left(\mathrm{NO}_{3}\right)_{4}$ solution, much dense region is found among the pore structure as shown in Figure 2(c). Interestingly, the pore structure and surface characterizations at the edge (Figure 2(f)) are similar to the fiber soaked with $100 \mathrm{mM}$ $\mathrm{UO}_{2}\left(\mathrm{NO}_{3}\right)_{4}$ solution. But inside of the fiber (Figure 2(i)), it is much similar to the fiber soaked with water. As well known, the thorium ion can be easily hydrolyzed at $\mathrm{pH}>3$ and form thorium precipitate. The $\mathrm{pH}$ value of $100 \mathrm{mM} \mathrm{Th}\left(\mathrm{NO}_{3}\right)_{4}$ solution is about 3, thus the dense regions might be of thorium precipitate adsorbed on the fiber, blocking the pore structure. Therefore, thorium ion could not go inside of the fiber through the pore structure. This is the reason that the thorium compound is only found on the surface of fiber.

Structural characterization of uranyl and thorium in the UHMWPE- $g$-PAO fiber

In order to identify the structural characterization of uranyl and thorium in the UHMWPE- $g$-PAO fiber, the SR-FTIR spectra of the single fiber samples are recorded and shown in Figure 3. The SR-FTIR spectra of UHMWPE- $g$-PAO fiber soaked with water, $0.2 \% \mathrm{HNO}_{3}$ solution, $100 \mathrm{mM} \mathrm{UO}_{2}\left(\mathrm{NO}_{3}\right)_{4}$ solution and $100 \mathrm{mM} \mathrm{Th}\left(\mathrm{NO}_{3}\right)_{4}$ solution are measured. The vibrational bands of C-H stretching at 2926 and $2853 \mathrm{~cm}^{-1}$ and 

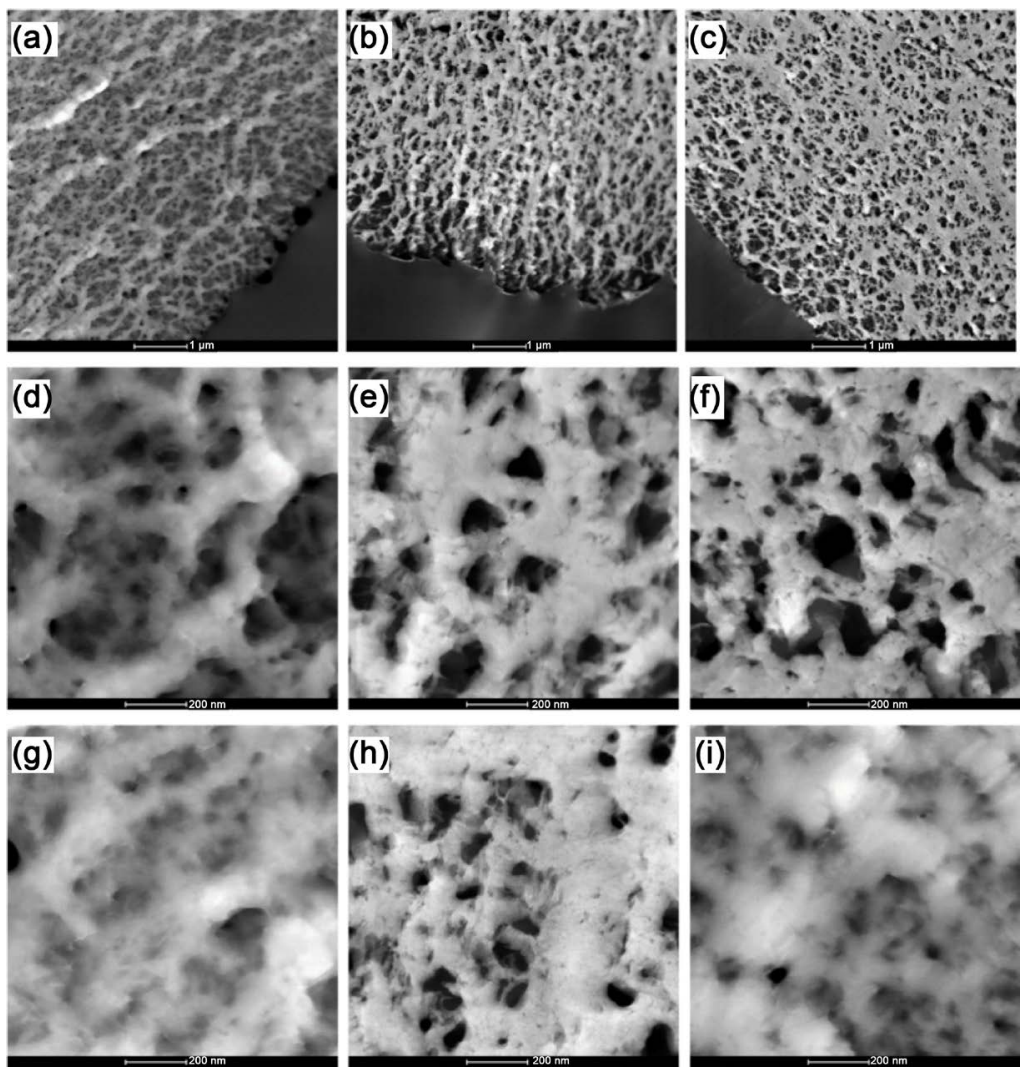

Figure 2. STEM images of UHMWPE- $g$-PAO fiber soaked with water ((a), (d), (g)), $100 \mathrm{mM}$ $\mathrm{UO}_{2}\left(\mathrm{NO}_{3}\right)_{4}$ solution ((b), (e), (h)) and $100 \mathrm{mM} \mathrm{Th}\left(\mathrm{NO}_{3}\right)_{4}$ solution ((c),(f),(i)).

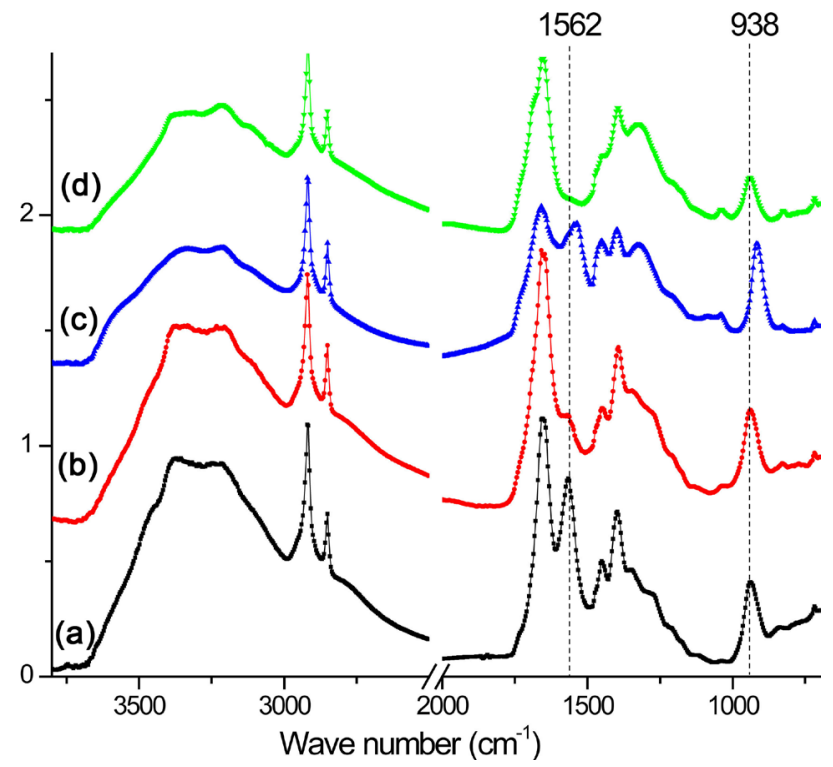

Figure 3. FTIR spectrum of the single UHMWPE- $g$-PAO fiber after absorption. (a) water, (b) $0.2 \% \mathrm{HNO}_{3}$ solution, (c) $100 \mathrm{mM} \mathrm{UO}_{2}\left(\mathrm{NO}_{3}\right)_{4}$ solution, and (d) $100 \mathrm{mM} \mathrm{Th}\left(\mathrm{NO}_{3}\right)_{4}$ solution.

that of $\mathrm{C}=\mathrm{N}$ at $1654 \mathrm{~cm}^{-1}$ were observed in all the four samples. The stretching frequencies at $1562 \mathrm{~cm}^{-1}$ and $938 \mathrm{~cm}^{-1}$ are due to $-\mathrm{NH}_{2}$ and $\mathrm{NO}_{2}$, respectively after soaking in water. After soaking with $0.2 \% \mathrm{HNO}_{3}$ solution, the band vibration of $-\mathrm{NH}_{2}$ at $1562 \mathrm{~cm}^{-1}$ disappeared, which might be caused by the reaction between the amino 
group and $\mathrm{H}^{+}$as shown in Equation (1). Meanwhile, no nitrate ions as counter ions are absorbed on the fiber. After soaking with $100 \mathrm{mM} \mathrm{UO}_{2}\left(\mathrm{NO}_{3}\right)_{4}$ solution, two shifts of the $\mathrm{N}-\mathrm{O}$ band from $938 \mathrm{~cm}^{-1}$ to $914 \mathrm{~cm}^{-1}$ and the $-\mathrm{NH}_{2}$ band from $1562 \mathrm{~cm}^{-1}$ to $1536 \mathrm{~cm}^{-1}$ are observed in the FTIR spectra. These shifts are not found in the fiber soaked with water and $0.2 \% \mathrm{HNO}_{3}$ solution. It might be caused by the coordination between $=\mathrm{N}-\mathrm{O}-$ groups and $\mathrm{UO}_{2}^{2+}$ [7] [12] [31], which is the most important and stable ion in acid aqueous solution (Equation (2)) [17]. The decreasing of the ratio between the band $\mathrm{C}=\mathrm{N}$ and the $-\mathrm{NH}_{2}$ band shift might be also caused by the coordination of $\mathrm{UO}_{2}^{2+}$. After soaking with $100 \mathrm{mM} \mathrm{Th}\left(\mathrm{NO}_{3}\right)_{4}$ solution, the FTIR spectra are almost the same as the spectra of fiber soaked with $0.2 \% \mathrm{HNO}_{3}$ solution. It means that enough $\mathrm{H}^{+}$should exist in $0.2 \% \mathrm{HNO}_{3}$ solution and $100 \mathrm{mM} \mathrm{Th}\left(\mathrm{NO}_{3}\right)_{4}$ solution, and will react with amidoxime groups in the fiber, as shown in Equation (1). This will lead to an increase of $\mathrm{pH}$ followed by precipitation of thorium due to hydrolysis and accumulating on the surface of the fiber.

$$
\begin{gathered}
\mathrm{R}-\mathrm{C}(\mathrm{NOH})-\mathrm{NH}_{2}+\mathrm{H}^{+} \rightarrow \mathrm{R}-\mathrm{C}(\mathrm{NOH})-\mathrm{N}^{+} \mathrm{H}_{3} \\
2 \mathrm{R}-\mathrm{C}\left(\mathrm{NH}_{2}\right)-\mathrm{NOH}+\mathrm{UO}_{2}^{2+} \rightarrow\left(\mathrm{UO}_{2}\right)\left(\mathrm{R}-\mathrm{C}\left(\mathrm{NH}_{2}\right)-\mathrm{NO}\right)_{2}+2 \mathrm{H}^{+}
\end{gathered}
$$

The EXAFS spectra are applied to understand the coordination environment of PAO-uranyl bonding after the fiber soaked with $100 \mathrm{mM} \mathrm{UO}_{2}\left(\mathrm{NO}_{3}\right)_{4}$ solution. The $k^{3}$-weighted EXAFS data and their corresponding FT are shown in Fig.4. The spectra A and spectra $B$ have clearly different oscillation mode in the range of $6 \AA^{-1}-8.5 \AA^{-1}$, and also shows a significantly difference in the intensity of the FT peak at $\sim 2 \AA$ (without phase shift). With the results of EXAFS fitting parameters as shown in Table 1, the two axial oxygen atoms $\left(\mathrm{O}_{\mathrm{ax}}\right)$ at a distance of $\sim 1.77 \AA$ as the typical of uranyl compound are found in the two samples. Five equatorial oxygen atoms $\left(\mathrm{O}_{\mathrm{eq}}\right)$ at a distance of $2.41 \AA$ were also found in the sample of $100 \mathrm{mM} \mathrm{UO}_{2}\left(\mathrm{NO}_{3}\right)_{4}$ solution. This result is consistent with the structure of $\mathrm{UO}_{2}\left(\mathrm{H}_{2} \mathrm{O}\right)_{5}^{2+}$ [32] [33] [34]. For the fiber sample after soaking with $100 \mathrm{mM} \mathrm{UO}_{2}\left(\mathrm{NO}_{3}\right)_{4}$ solution, four oxygen atoms at range of $2.3-3.2 \AA$ (two at $\sim 2.36 \AA$ and other two at $\sim 2.51 \AA$ ) and one nitrogen atom at $\sim 2.48 \AA$ also can be seen. This result is similar to the uranyl compound of $\left[\mathrm{UO}_{2}\right]\left[\mathrm{NH}_{2}\right]_{2} \mathrm{O}_{2}\left[\mathrm{H}_{2} \mathrm{O}\right]_{3}[35]$ crystal and uranyl hydroxo complex [36]. Compared with these previous results, it is suggested that the uranyl ion is surrounded by hydroxyl groups and water molecules but for the amidoxime group on the surface of the fiber. With the above FTIR results, no nitrate ions as counter ions adsorbed on the fiber. And two band shifts ( $\mathrm{N}-\mathrm{O}$ band and $-\mathrm{NH}_{2}$ band) were happened in the fiber after soaking. Therefore, two amidoxime groups (U-N and $\left.\mathrm{U}-\mathrm{O}_{\mathrm{eq}}\right)$ and two water molecules $\left(\mathrm{U}-\mathrm{O}_{\mathrm{eq} 2}\right)$ as ligand coordinate with uranyl ion are existed in the fiber samples and the proposed structural of uranyl compound in UHMWPE- $g$-PAO fiber is shown in Figure 4.

Besides, EXAFS spectra of Th -loaded fiber after soaking in $100 \mathrm{mM} \mathrm{Th}\left(\mathrm{NO}_{3}\right)_{4}$ was also recorded (Figure 5). As a reference, the spectra of $\mathrm{Th}(\mathrm{OH})_{4}$ precipitate reported by Shi [37] are also presented in Figure 5. It is seen that the spectra of Th in UHMWPE-gPAO fiber and $\mathrm{Th}(\mathrm{OH})_{4}$ precipitate show almost same oscillation mode and the same intense FT peaks in the range of $1-4 \AA$ without phase shift. There is a small peak at $\sim 2.5 \AA$ in $\mathrm{Th}\left(\mathrm{NO}_{3}\right)_{4}$ solution, which is not found in other two samples. Combined with 
the above FTIR results, no nitrate ions as counter ions absorbed on the fiber. Therefore, the thorium ions in fiber might exist as the compound of $\mathrm{Th}(\mathrm{OH})_{4}$ precipitate.

\section{Adsorption behavior of UHMWPE- $g$-PAO fiber}

The adsorption behavior of UHMWPE- $g$-PAO fiber to the uranyl and thorium ions is determined by ICP-AES and shown in Figure 6. According to FTIR and EXAFS results, uranyl sorption by the fiber was involved a specific number of chelating sites and thus compatible with the Langmuir model [38]. The fitting of data by Langmuir isotherm

Table 1. EXAFS fit parameters extracted by a least-squares fitting analysis.

\begin{tabular}{|c|c|c|c|c|c|c|}
\hline Sample & Shell & $\mathrm{R}^{\mathrm{a}}[\AA]$ & $\mathrm{N}^{b}$ & $\sigma^{2 c}\left[\AA^{2}\right]$ & $\Delta \mathrm{E}^{d}(\mathrm{eV})$ & $\mathrm{R}$-factor ${ }^{e}$ \\
\hline \multirow{2}{*}{ Uranyl in solution } & $\mathrm{U}-\mathrm{O}_{\mathrm{ax}}$ & $1.77 \pm 0.01$ & $2^{f}$ & $0.0014 \pm 0.0002$ & \multirow{2}{*}{2.1} & \multirow{2}{*}{0.016} \\
\hline & $\mathrm{U}-\mathrm{O}_{\mathrm{eq} 2}$ & $2.41 \pm 0.01$ & 5.1 & $0.0006 \pm 0.0007$ & & \\
\hline \multirow{4}{*}{ Uranyl in fiber } & $\mathrm{U}-\mathrm{O}_{\mathrm{ax}}$ & $1.79 \pm 0.01$ & $2^{f}$ & $0.006 \pm 0.002$ & \multirow{4}{*}{3.9} & \multirow{4}{*}{0.016} \\
\hline & $\mathrm{U}-\mathrm{O}_{\mathrm{eq} 1}$ & $2.36 \pm 0.03$ & 2.2 & $0.004 \pm 0.001$ & & \\
\hline & U-N & $2.48 \pm 0.03$ & 2.1 & $0.004 \pm 0.001$ & & \\
\hline & $\mathrm{U}-\mathrm{O}_{\mathrm{eq} 2}$ & $2.51 \pm 0.03$ & 1.9 & $0.004 \pm 0.002$ & & \\
\hline
\end{tabular}

${ }^{a}$ Interatomic distance. ${ }^{b}$ Coordination number: $\mathrm{N} \pm \sim 20 \%$. Debye-Waller factor. ${ }^{d}$ Energy shift linked for all the paths. ${ }^{e}$ Goodness of fit parameter. Fixed parameter.

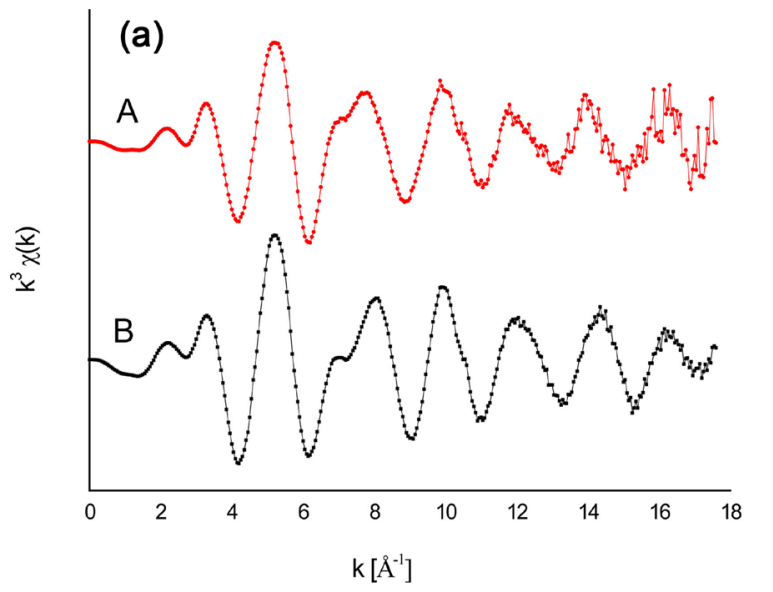

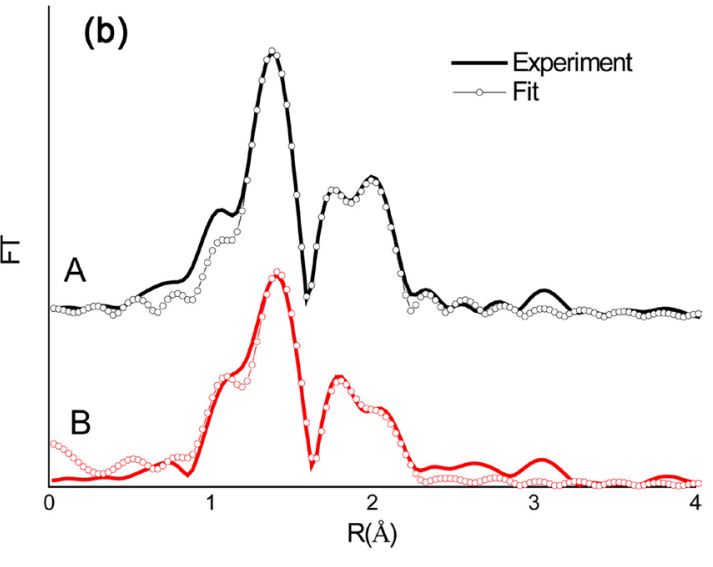

UHMWPE-g-PAO fiber

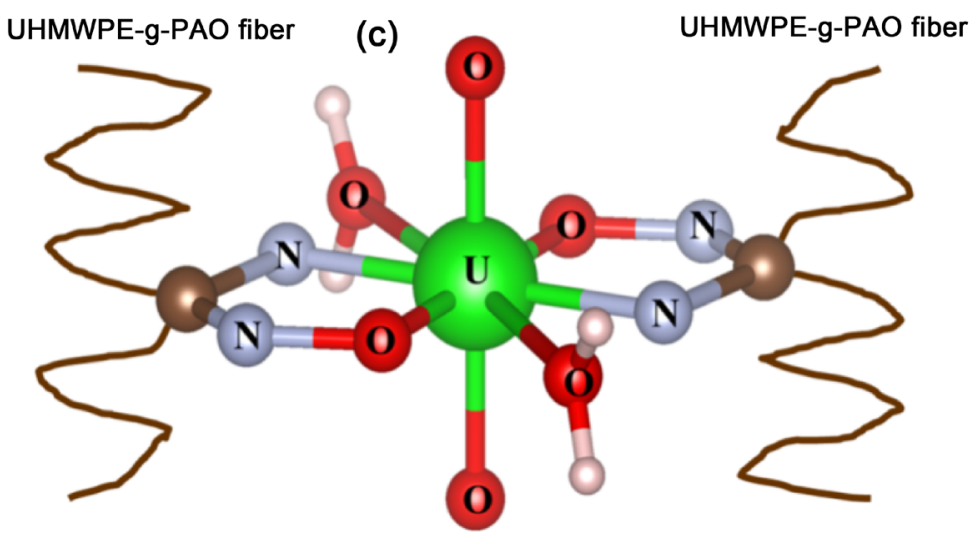

Figure 4. (a): Raw $\mathrm{U} \mathrm{L}_{3}$-edge $k^{3}$-weight EXAFS data of $100 \mathrm{mM} \mathrm{UO}_{2}\left(\mathrm{NO}_{3}\right)_{4}$ solution (A) and UHMWPE fiber soaked with $100 \mathrm{mM} \mathrm{UO}_{2}\left(\mathrm{NO}_{3}\right)_{4}$ solution (B); (b): corresponding Fourier transforms. The FT spectra are not corrected for phase shift; (c): Proposed structural of uranyl complexes in the fiber. 

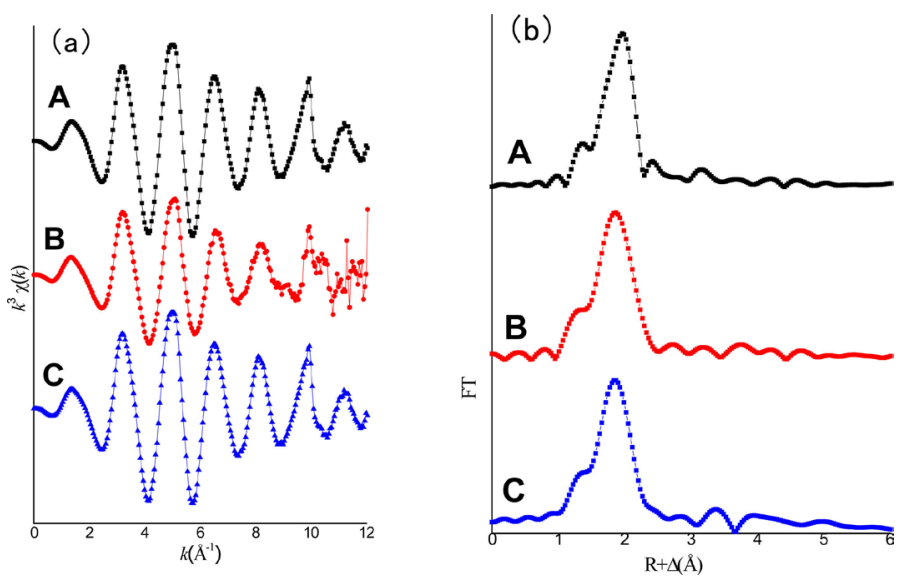

Figure 5. (a): Raw Th $\mathrm{L}_{3}$-edge $k^{3}$-weight EXAFS data of $100 \mathrm{mM} \mathrm{Th}\left(\mathrm{NO}_{3}\right)_{4}$ solution (A), UHMWPE fiber soaked with $100 \mathrm{mM} \mathrm{Th}\left(\mathrm{NO}_{3}\right)_{4}$ solution (B) and $\mathrm{Th}(\mathrm{OH})_{4}$ precipitate(C); (b): corresponding Fourier transforms. The FT spectra are not corrected for phase shift.
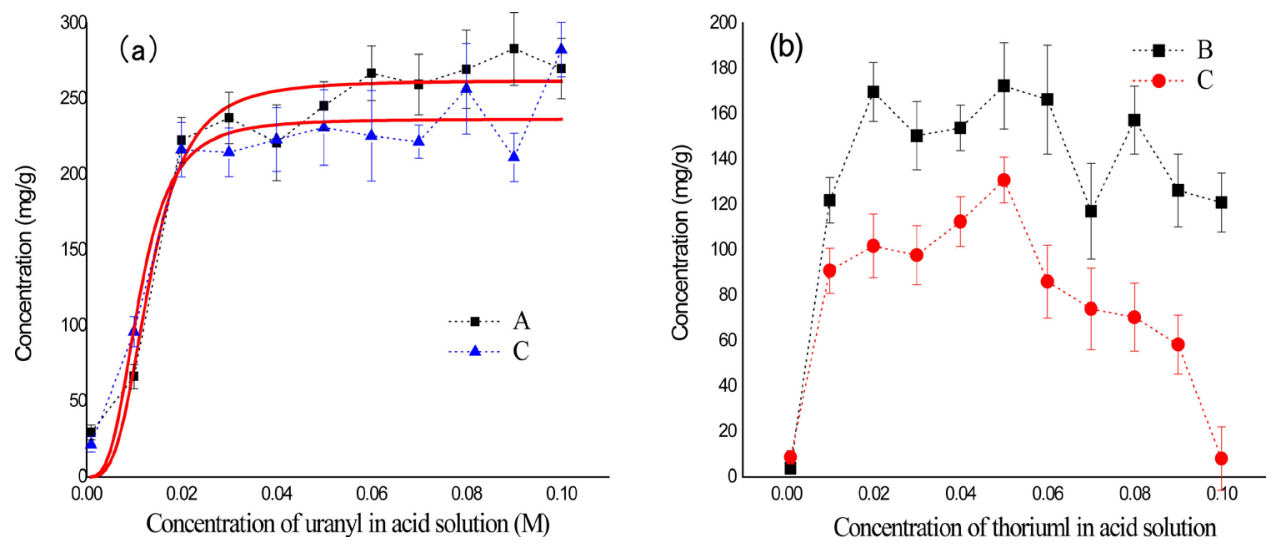

Figure 6. Sorption capacity of uranyl (a) and thorium (b) by UHMWPE- $g$-PAO fiber. $\mathrm{UO}_{2}\left(\mathrm{NO}_{3}\right)_{4}$ solution (A), Th $\left(\mathrm{NO}_{3}\right)_{4}$ solution (B) and their mixed solution (C).

model is shown in Figure 6(a). The uranyl ion sorption capacities of the fiber soaked with $\mathrm{UO}_{2}\left(\mathrm{NO}_{3}\right)_{4}$ solution and mixed solution are estimated to be about $262.01 \mathrm{mg} / \mathrm{g}$ and $236.69 \mathrm{mg} / \mathrm{g}$, respectively, when the uranyl ion concentration is higher than 30 $\mathrm{mM}$. The uranyl adsorption capacities of fiber are similar in two acid solutions. Besides, the maximum thorium ion adsorption capacity of fiber is about $160 \mathrm{mg} / \mathrm{g}$ and $100 \mathrm{mg} / \mathrm{g}$ after soaking with thorium solution and mixed solution, separately. And the thorium sorption capacity of fiber is significantly different with different solution concentrations. Interestingly, the thorium ion sorption capacity of the fiber is significantly decreased when thorium concentration is higher than $60 \mathrm{mM}$. This result indicates that uranyl sorption capacity of the fiber is stable, and not interrupted by thorium ion. But the thorium sorption capacity is much lower in the presence of uranyl ion. For uranyl ions in acid solution, it can penetrate the fiber through the connected pore structures, forming $\left(\mathrm{UO}_{2}\right)\left(\mathrm{R}-\mathrm{C}\left(\mathrm{NH}_{2}\right)-\mathrm{NO}\right)_{2}$ chelates with the amidoxime groups within the fiber. Uranium adsorption was not interrupted by co-existing with thorium ions. The $\mathrm{Th}(\mathrm{OH})_{4}$ precipitate was formed with decrease of $\mathrm{H}^{+}$ions in the acid solution. And the precipitate thus blocked the connected pore structures. Therefore, the uranyl sorption capacity of fiber is much higher that thorium. For mixed acid solution, the increasing of 
the uranyl concentration, more $\mathrm{H}^{+}$will be produced with the reaction between the amidoxime group in fiber and uranyl ions. Therefore, hydrolysis of thorium ion could not happen anymore when $\mathrm{pH}$ value is lower than 2. This phenomenon explains why the thorium ion sorption capacity of the fiber is significantly decreased in the mixed solution of uranyl and thorium ion at the concentration of $100 \mathrm{mM}$. The UHMWPE- $g$ PAO fiber is thus emerged as a new sorbent with more selective toward uranyl ion over vanadium.

\section{Ultimate Processing}

The UHMWPE- $g$-PAO fibers were collected after adsorption, and sintered in an electric muffle furnace in the presence of air to $1200^{\circ} \mathrm{C}$ for $12 \mathrm{~h}$. The sintering products were observed with SEM (Figure 7). The uneven uranium particulate matter, formed as uranium oxide, with diameter range from $500 \mathrm{~nm}$ to $20 \mu \mathrm{m}$ was obtained (Figure 7 (a) and Figure $7(\mathrm{~b})$ ). The final products are thorium dioxide particles with diameter ranging from 100 to $200 \mathrm{~nm}$ (Figure 7(c) and Figure 7(d)). Therefore, the uranium and thorium oxide particles were collected after high temperature treatment. The volume of acid aqueous solution containing uranyl and thorium ion was minimized as solid
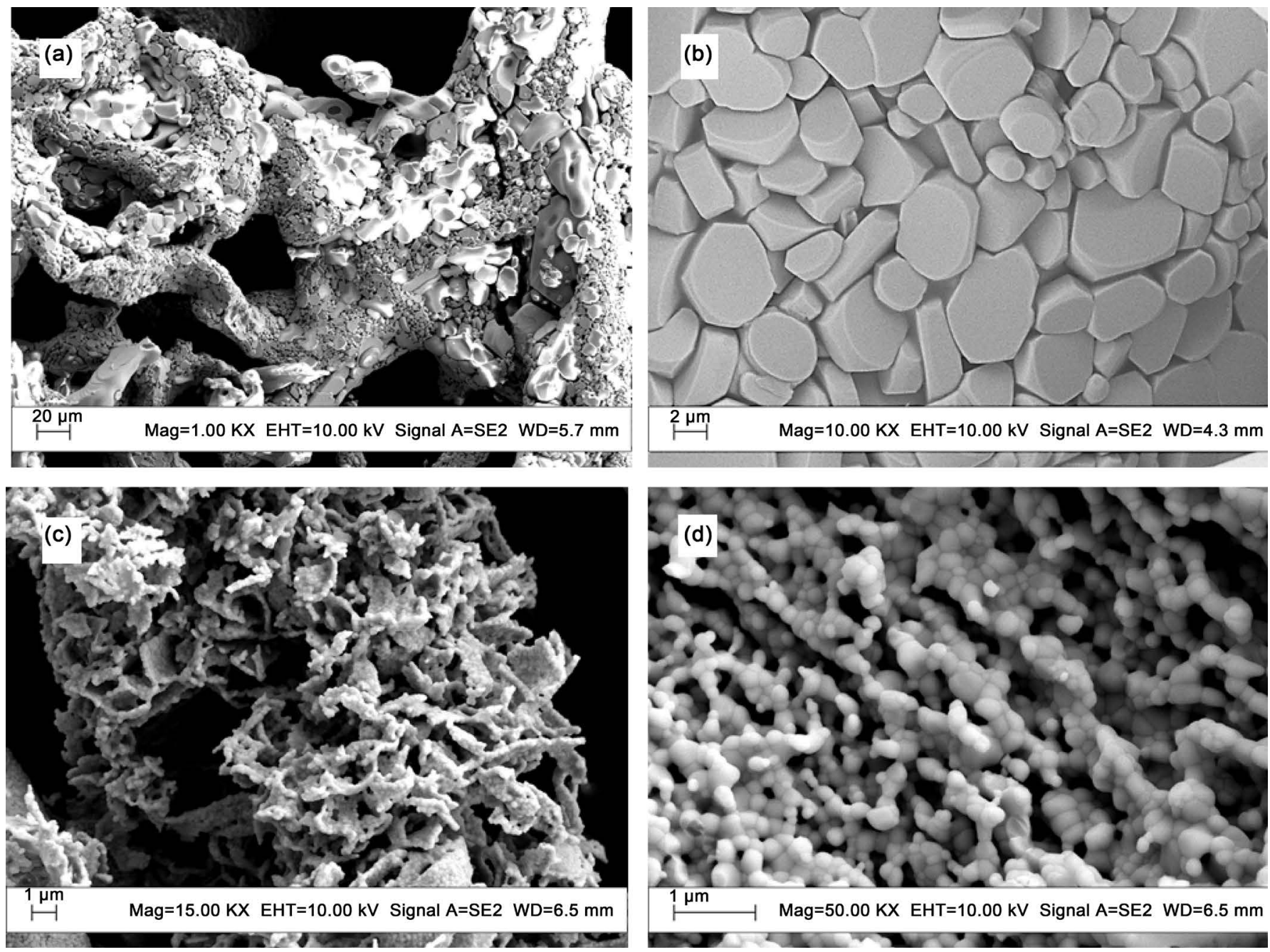

Figure 7. SEM images of ultimate products: the fiber soaking with $\mathrm{UO}_{2}\left(\mathrm{NO}_{3}\right)_{4}$ solution ((a), (b)), and the fiber soaking with $\mathrm{Th}\left(\mathrm{NO}_{3}\right)_{4}$ solution $((\mathrm{c}),(\mathrm{d}))$. 


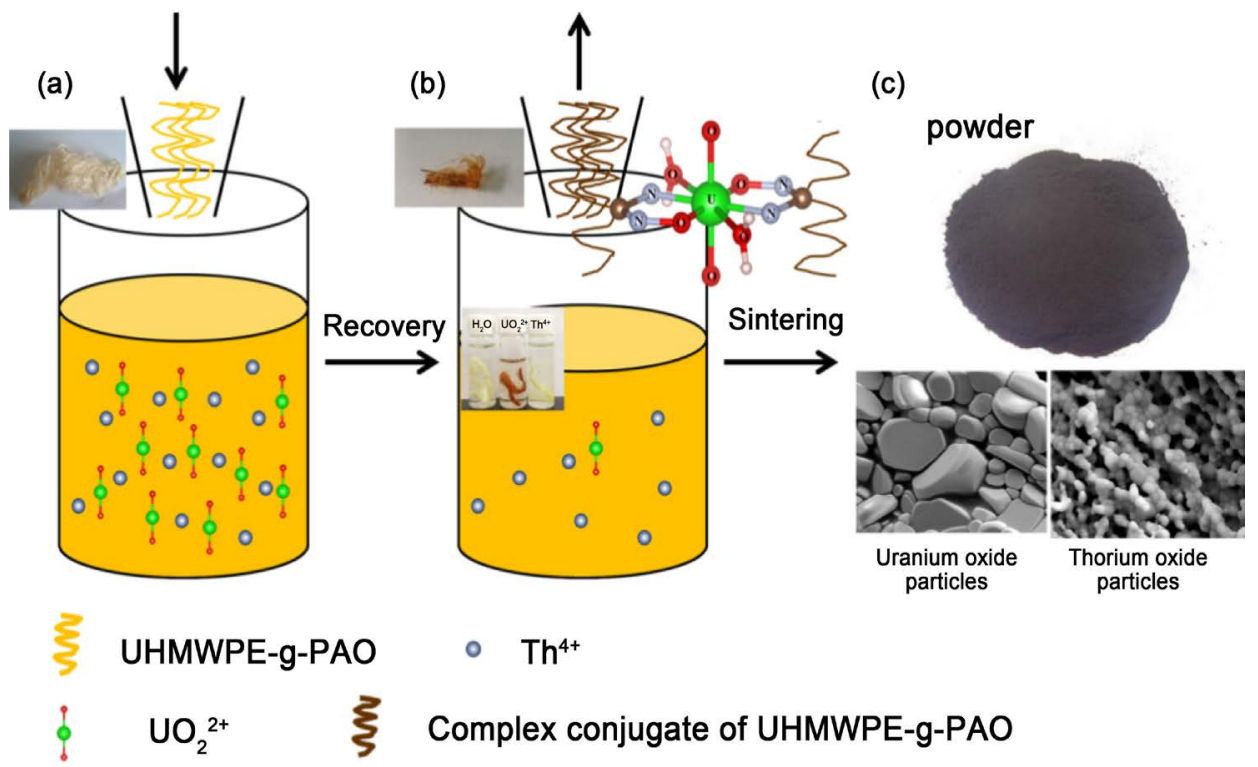

Figure 8. The process of the amidoximated-UHMEPE fiber removal of uranyl and thorium from acid aqueous solution. ((a), (b)) Recovery of uranyl and thorium with UHMWPE-g-PAO fiber; (c) Sintering fier process (volume reduction).

powders with the adsorption of UHMWPE- $g$-PAO fibers and sintering. Moreover, the process was environmentally friendly.

\section{Conclusion}

In this work, a new polymer fiber adsorbent (UHMEPE-g-PAO fiber), prepared by amidoximation of grafted polyacrylonitrile onto ultra high molecular weight polyethylene (UHMWPE) fiber, was used to remove the uranyl and thorium ions from acid aqueous solutions and its performance was carefully investigated. The results indicated that uranyl ion can penetrate the fiber through the connected pore structures, forming $\left(\mathrm{UO}_{2}\right)\left(\mathrm{R}-\mathrm{C}\left(\mathrm{NH}_{2}\right)-\mathrm{NO}\right)_{2}$ chelates with the amidoxime groups within the fiber. And it was also found that two amidoxime groups (U-N and $\mathrm{U}-\mathrm{O}_{\mathrm{eq}}$ ) and two water molecules $\left(\mathrm{U}-\mathrm{O}_{\mathrm{eq} 2}\right)$ are bound to uranyl ion in the fiber. On the contrary, thorium ions are adsorbed mainly on the fiber surface in the form of $\mathrm{Th}(\mathrm{OH})_{4}$ precipitate that blocks the entrance of $\mathrm{Th}^{4+}$ ion into fiber pores. Moreover, the maximum adsorption capacities of uranyl and thorium ions by this fiber were estimated to be $262.01 \mathrm{mg} / \mathrm{g}$ and $160 \mathrm{mg} / \mathrm{g}$ at room temperature with $\mathrm{pH} 3.0$, respectively. From our results, it indicates that the UHMWPE- $g$-PAO fiber has higher adsorption selectivity for uranyl ion than thorium ion. Uranium and thorium oxide particles were obtained as the ultimate product after sintering of the fiber adsorbent. The process of the amidoximated-UHMEPE fiber removal of uranyl and thorium from acid aqueous solution was shown in Figure 8. This novel and environmentally friendly adsorption process is feasible to extract uranium or thorium from acidic aqueous solution.

\section{Acknowledgements}

This work was supported by the Program of International S\&T Cooperation (2014DFG60230), Natural Science Foundation of China (No. 11105221, 11275256, 11179024 
and 21306220).

\section{References}

[1] Bai, Z.Q., Li, Z.J., Wang, C.Z., Yuan, L.Y., Liu, Z.R., Zhang, J., Zheng, L.R., Zhao, Y.L., Chai, Z.F. and Shi, W.Q. (2014) Interactions between Th(IV) and Graphene Oxide: Experimental and Density Functional Theoretical Investigations. RSC Advances, 4, 3340-3347. https://doi.org/10.1039/C3RA45938A

[2] Sun, Y., Shao, D., Chen, C., Yang, S. and Wang, X. (2013) Highly Efficient Enrichment of Radionuclides on Graphene Oxide-Supported Polyaniline. Environmental Science \& Technology, 47, 9904-9910. https://doi.org/10.1021/es401174n

[3] Mertz, J.L., Fard, Z.H., Malliakas, C.D., Manos, M.J. and Kanatzidis, M.G. (2013) Selective Removal of $\mathrm{Cs}^{+}, \mathrm{Sr}^{2+}$, and $\mathrm{Ni}^{2+}$ by $\mathrm{K}_{2 \mathrm{x}} \mathrm{Mg}_{\mathrm{x}} \mathrm{Sn}_{3-\mathrm{x}} \mathrm{S}_{6}(\mathrm{x}=0.5-1)$ (KMS-2) Relevant to Nuclear Waste Remediation. Chemistry of Materials, 25, 2116-2127. https://doi.org/10.1021/cm400699r

[4] Bai, Z.C., Zhang, Y.H., Zhang, Y.W., Guo, C.L., Tang, B. and Sun, D. (2015) MOFs-Derived Porous $\mathrm{Mn}_{2} \mathrm{O}_{3}$ as High-Performance Anode Material for Li-Ion Battery. Journal of Materials Chemistry $A, 3,5266-5269$. https://doi.org/10.1039/C4TA06292B

[5] Yang, X.D., Li, J., Liu, J., Tian, Y., Li, B., Cao, K.C., Liu, S.B., Hou, M., Li, S.J. and Ma, L.J. (2014) Simple Small Molecule Carbon Source Strategy for Synthesis of Functional Hydrothermal Carbon: Preparation of Highly Efficient Uranium Selective Solid Phase Extractant. Journal of Materials Chemistry A, 2, 1550-1559. https://doi.org/10.1039/C3TA13949B

[6] Buszewski, B. and Szultka, M. (2012) Past, Present, and Future of Solid Phase Extraction: A Review. Critical Reviews in Analytical Chemistry, 42, 198-213. https://doi.org/10.1080/07373937.2011.645413

[7] Zhao, Y.G., Li, J.X., Zhao, L.P., Zhang, S.W., Huang, Y.S., Wu, X.L. and Wang, X.K. (2014) Synthesis of Amidoxime-Functionalized $\mathrm{Fe}_{3} \mathrm{O}_{4} @ \mathrm{SiO}_{2}$ Core-Shell Magnetic Microspheres for Highly Efficient Sorption of U(VI). Chemical Engineering Journal, 235, 275-283. https://doi.org/10.1016/j.cej.2013.09.034

[8] Anirudhan, T.S., Bringle, C.D. and Rijith, S. (2010) Removal of Uranium(VI) from Aqueous Solutions and Nuclear Industry Effluents Using Humic Acid-Immobilized Zirconium-Pillared Clay. Journal of Environmental Radioactivity, 101, 267-276. https://doi.org/10.1016/j.jenvrad.2009.12.001

[9] Bai, Z.Q., Yuan, L.Y., Zhu, L., Liu, Z.R., Chu, S.Q., Zheng, L.R., Zhang, J., Chai, Z.F. and Shi, W.Q. (2015) Introduction of Amino Groups into Acid-Resistant MOFs for Enhanced U(VI) Sorption. Journal of Materials Chemistry A, 3, 525-534. https://doi.org/10.1039/C4TA04878D

[10] Akkaya, R. (2013) Uranium and Thorium Adsorption from Aqueous Solution Using a Novel Polyhydroxyethylmethacrylate-Pumice Composite. Journal of Environmental Radioactivity, 120, 58-63. https://doi.org/10.1016/j.jenvrad.2012.11.015

[11] Akkaya, R. and Akkaya, B. (2013) Adsorption Isotherms, Kinetics, Thermodynamics and Desorption Studies for Uranium and Thorium Ions from Aqueous Solution by Novel Microporous Composite P (HEMA-EP). Journal of Nuclear Materials, 434, 328-333. https://doi.org/10.1016/j.jnucmat.2012.11.056

[12] Das, S., Pandey, A.K., Athawale, A.A. and Manchanda, V.K. (2009) Exchanges of Uranium(VI) Species in Amidoxime-Functionalized Sorbents. The Journal of Physical Chemistry $B, 113,6328-6335$. https://doi.org/10.1021/jp8097928

[13] Wang, Y., Gu, Z.X., Yang, J.J., Liao, J.L., Yang, Y.Y., Liu, N. and Tang, J. (2014) Amidoxime-Grafted Multiwalled Carbon Nanotubes by Plasma Techniques for Efficient Removal of Uranium(VI). Applied Surface Science, 320, 10-20. 
https://doi.org/10.1016/j.apsusc.2014.08.182

[14] Abbasizadeh, S., Keshtkar, A.R. and Mousavian, M.A. (2013) Preparation of a Novel Electrospun Polyvinyl Alcohol/Titanium Oxide Nanofiber Adsorbent Modified with Mercapto groups for Uranium(VI) and Thorium(IV) Removal from Aqueous Solution. Chemical Engineering Journal, 220, 161-171. https://doi.org/10.1016/j.cej.2013.01.029

[15] Liu, X.Y., Liu, H.Z., Ma, H.J., Cao, C.Q., Yu, M., Wang, Z.Q., Deng, B., Wang, M. and Li, J.Y. (2012) Adsorption of the Uranyl Ions on an Amidoxime-Based Polyethylene Nonwoven Fabric Prepared by Preirradiation-Induced Emulsion Graft Polymerization. Industrial \& Engineering Chemistry Research, 51, 15089-15095. https://doi.org/10.1021/ie301965g

[16] Pan, H.B., Liao, W., Wai, C.M., Oyola, Y., Janke, C.J., Tian, G. and Rao, L. (2014) Carbonate- $\mathrm{H}_{2} \mathrm{O}_{2}$ Leaching for Sequestering Uranium from Seawater. Dalton Transactions, 43, 10713-10718. https://doi.org/10.1039/c3dt53404a

[17] Humelnicu, D., Dinu, M.V. and Dragan, E.S. (2011) Adsorption Characteristics of $\mathrm{UO}_{2}{ }^{2+}$ and $\mathrm{Th}^{4+}$ Ions from Simulated Radioactive Solutions onto Chitosan/Clinoptilolite Sorbents. Journal of Hazardous Materials, 185, 447-455. https://doi.org/10.1016/j.jhazmat.2010.09.053

[18] Xing, Z., Wang, M.H., Liu, W.H., Hu, J.T. and Wu, G.Z. (2013) Crystal Structure and Mechanical Properties of UHMWPE-g-PMA Fiber Prepared by Radiation Grafting. Radiation Physics and Chemistry, 86, 84-89. https://doi.org/10.1016/j.radphyschem.2013.01.045

[19] Xing, Z., Hu, J.T., Wang, M.H., Zhang, W.L., Li, S.N., Gao, Q.H. and Wu, G.Z. (2013) Properties and Evaluation of Amidoxime-Based UHMWPE Fibrous Adsorbent for Extraction of Uranium from Seawater. Science China Chemistry, 56, 1504-1509. https://doi.org/10.1007/s11426-013-5002-x

[20] Hu, J.T., Ma, H.J., Xing, Z., Liu, X.Y., Xu, L., Li, R., Lin, C.J., Wang, M.H., Li, J.Y. and Wu, G.Z. (2016) Preparation of Amidoximated Ultrahigh Molecular Weight Polyethylene Fiber by Radiation Grafting and Uranium Adsorption Test. Industrial \& Engineering Chemistry Research, 55, 4118-4124.

[21] Chen, R.C., Dreossi, D., Mancini, L., Menk, R., Rigon, L., Xiao, T.Q. and Longo, R. (2012) PITRE: Software for Phase-Sensitive X-Ray Image Processing and Tomography Reconstruction. Journal of Synchrotron Radiation, 19, 836-845. https://doi.org/10.1107/S0909049512029731

[22] Liu, X.J., Zhu, H.L. and Liang, L.X. (2014) Digital Rock Physics of Sandstone Based on Micro-CT Technology. Chinese Journal of Geophysics-Chinese Edition, 57, 1133-1140.

[23] Ferreira, E.S.B., Boon, J.J., van der Horst, J., Scherrer, N.C., Marone, F. and Stampanoni, M. (2009) 3D Synchrotron X-Ray Microtomography of Paint Samples. Proceedings of SPIE, 7391, 73910L-1-73910L-8. https://doi.org/10.1117/12.827511

[24] Ravel, B. and Newville, M. (2005) ATHENA, ARTEMIS, HEPHAESTUS: Data Analysis for X-Ray Absorption Spectroscopy Using IFEFFIT. Journal of Synchrotron Radiation, 12, 537541. https://doi.org/10.1107/S0909049505012719

[25] Newville, M. (2001) IFEFFIT: Interactive XAFS Analysis and FEFF Fitting. Journal of Synchrotron Radiation, 8, 322-324. https://doi.org/10.1107/S0909049500016964

[26] Nakanishi, K. and Ohta, T. (2009) Verification of the FEFF Simulations to K-Edge XANES Spectra of the Third Row Elements. Journal of Physics. Condensed Matter, 21, Article ID: 104214.

[27] Eustace, D.A., McComb, D.W. and Craven, A.J. (2010) Probing Magnetic Order in EELS of Chromite Spinels Using both Multiple Scattering (FEFF8.2) and DFT (WIEN2k). Micron, 41, 547-553. https://doi.org/10.1016/j.micron.2010.04.013

[28] Lavrentyev, A.A., Nikiforov, I.Y., Dubeiko, V.A., Gabrelian, B.V. and Rehr, J.J. (2001) The 
Use of the FEFF8 Code to Calculate the XANES and Electron Density of States of Some Sulfides. Journal of Synchrotron Radiation, 8, 288-290. https://doi.org/10.1107/S0909049500018938

[29] Belloni, F., Kuetahyali, C., Rondinella, V.V., Carbol, P., Wiss, T. and Mangione, A. (2009) Can Carbon Nanotubes Play a Role in the Field of Nuclear Waste Management? Environmental Science \& Technology, 43, 1250-1255. https://doi.org/10.1021/es802764g

[30] Yue, Y.F., Mayes, R.T., Kim, J., Fulvio, P.F., Sun, X.G., Tsouris, C., Chen, J.H., Brown, S. and Dai, S. (2013) Seawater Uranium Sorbents: Preparation from a Mesoporous Copolymer Initiator by Atom-Transfer Radical Polymerization. Angewandte Chemie International Edition, 52, 13458- 13462. https://doi.org/10.1002/anie.201307825

[31] Prestianni, A., Joubert, L., Chagnes, A., Cote, G., Ohnet, M.N., Rabbe, C., Charbonnel, M.C. and Adamo, C. (2010) IR Fingerprints of U(VI) Nitrate Monoamides Complexes: A Joint Experimental and Theoretical Study. Journal of Physical Chemistry A, 114, 10878-10884. https://doi.org/10.1021/jp106467p

[32] Vallet, V., Wahlgren, U., Schimmelpfennig, B., Szabo, Z. and Grenthe, I. (2001) The Mechanism for Water Exchange in [UO2(H2O)(5)](2+) and [UO2(oxalate)(2)(H2O)](2-), as Studied by Quantum Chemical Methods. Journal of the American Chemical Society, 123, 11999-12008. https://doi.org/10.1021/ja015935+

[33] Neuefeind, J., Soderholm, L. and Skanthakumar, S. (2004) Experimental Coordination Environment of Uranyl(VI) in Aqueous Solution. Journal of Physical Chemistry A, 108, 2733-2739. https://doi.org/10.1021/jp037997n

[34] Hennig, C., Schmeide, K., Brendler, V., Moll, H., Tsushima, S. and Scheinost, A.C. (2007) EXAFS Investigation of U(VI), U(IV), and Th(IV) Sulfato Complexes in Aqueous Solution. Inorganic Chemistry, 46, 5882-5892. https://doi.org/10.1021/ic0619759

[35] Adrian, H.W.W. and Vantets, A. (1977) Low-Temperature Neutron and X-Ray-Diffraction Study of $\mathrm{UO}_{2}\left(\mathrm{NH}_{2} \mathrm{O}\right)_{2} \cdot 3 \mathrm{H}_{2} \mathrm{O}$. Acta Crystallogr, B33, 2997-3000. https://doi.org/10.1107/S0567740877010127

[36] Tsushima, S., Rossberg, A., Ikeda, A., Muller, K. and Scheinost, A.C. (2007) Stoichiometry and Structure of Uranyl(VI) Hydroxo Dimer and Trimer Complexes in Aqueous Solution. Inorganic Chemistry, 46, 10819-10826. https://doi.org/10.1021/ic701607e

[37] Yuan, L.Y., Bai, Z.Q., Zhao, R., Liu, Y.L., Li, Z.J., Chu, S.Q., Zheng, L.R., Zhang, J., Zhao, Y.L., Chai, Z.F. and Shi, W.Q. (2014) Introduction of Bifunctional Groups into Mesoporous Silica for Enhancing Uptake of Thorium(IV) from Aqueous Solution. ACS Applied Materials \& Interfaces, 6, 4786-4796. https://doi.org/10.1021/am405584h

[38] Bryant, D.E., Stewart, D.I., Kee, T.P. and Barton, C.S. (2003) Development of a Functionalized Polymer-Coated Silica for the Removal of Uranium from Groundwater. Environmental Science \& Technology, 37, 4011-4016. https://doi.org/10.1021/es020178g 


\section{Appendix}
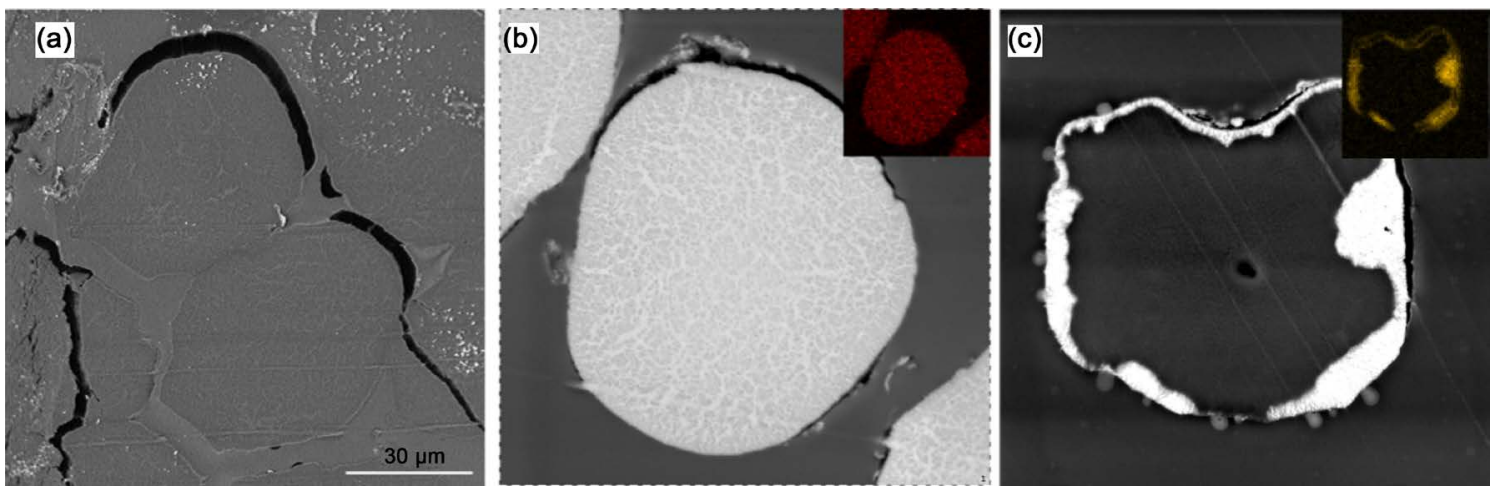

Figure S1. The SEM and EDX results of the UHMWPE-g-PAO fiber soaked with water (a), 0.1 M uranyl nitrate solution (b) and $0.1 \mathrm{M}$ thorium nitrate solution (c).

Submit or recommend next manuscript to SCIRP and we will provide best service for you:

Accepting pre-submission inquiries through Email, Facebook, LinkedIn, Twitter, etc. A wide selection of journals (inclusive of 9 subjects, more than 200 journals)

Providing 24-hour high-quality service

User-friendly online submission system

Fair and swift peer-review system

Efficient typesetting and proofreading procedure

Display of the result of downloads and visits, as well as the number of cited articles

Maximum dissemination of your research work

Submit your manuscript at: http://papersubmission.scirp.org/

Or contact aces@scirp.org 